\title{
The Effect Of Work Motivation And Transformational Leadership Style On Employee Performance Through Organizational Citizenship Behavior As An Internvening Variable On BMT UGT Sidogiri Jember Employees
}

\author{
${ }^{1}$ Lusi Oktaviani ${ }^{*}{ }^{2}$ Purnamie Titisari, ${ }^{3}$ Imam Suroso \\ ${ }^{1,2,3}$ Economic, Jember University, Indonesia
}

\begin{abstract}
The study aims to analyse and discuss work motivation variables and transformational leadership styles on employee performance, work motivation variables and transformational leadership styles in Organizational Citizenship Behaviour (OCB), and Organizatinal Citizenship Behaviour (OCB) variables on employee performance. The population in this study were all employees of BMT UGT SIDOGIRI Jember consisting of 152 people. The sampling method uses a sampling probability with a random sampling approach using the Sovlin formula so that a sample of 110 respondents is obtained. The research uses line analysis and SPSS 20.0 as an analytical tool. The results of this study are (1) The motivation of work is significant impact on Organizational Citizenship Behaviour of BMT UGT Sidogiri Jember Employees, (2) Transformational leadership style significant influence on Organizational Citizenship Behaviour on employees of BMT UGT Sidogiri Jember, (3) Work motivation is significant effect on the performance of BMT UGT Sidogiri Jember Employees, (4) The Transformational leadership style is significant to the performance of the employees of BMT UGT Sidogiri Jember , (5) Organizational Citizenship Behaviour has a significant effect on the performance of employees of BMT UGT Sidogiri Jember, (6) The motivation of work has a significant impact on performance through the Organizational Citizenship Behaviour on employees of BMT UGT Sidogiri Jember, (6) The Transformational leadership style is significant to the performance through the Organizational Citizenship Behaviour at BMT UGT Sidogiri
\end{abstract}

Keywords: Work Motivation, Transformational Leadership Style, Organizational Citizenship Behaviour, and Employee Performance.

\section{Introduction}

The educational institution of Pondok Pesantren is an educational institution that has long grown along with the history of Islamic development in Indonesia. With the character of self-reliance and distinctive educational style, the institution survives and continues to thrive in Indonesia, even regarded as the original face of Indonesian education. Among the education institutions in Indonesia, Pesantren is the oldest education system assessed as a result of long journey process. His existence and career as a socialCommunity institution engaged in education, teaching and Da'wah, proved to give great care in the formation and development of mental spiritual and community character, especially in rural areas. As the Pondok Pesantren Sidogiri Pasuruan which belongs to the oldest boarding school in East Java.

Based on the data reported by The Pew Forum on Religioun \& Public Life, Islamic adherents in Indonesia amounted to 209.1 million people or 87.2 percent of the total population. Indonesia's Muslim-majority need for Islamic financial institutions has made the Sharia financial institution sector a fairly prospective business option. After the success of the scientific generation both in the field of religion and general, the boarding school Sidogiri Pasuruan now penetrated the economic strength, by establishing BMT UGT Sidogiri since 17 July 1997 through cooperative legal entity number 608/BH/KWK. 13/IX/97. 


\section{Research objectives}

The aim of research is to know the work motivation and transformational leadership style to the employees ' performance Organizational Citizemship Behaviour as a variable intervening in BMT UGT Sidogiri Jember employees.

\section{Work motivation}

According to Mulyadi (2015:87) motivation is a good encouragement from other people as well as of himself to work on a job with conscious and spirit to achieve a certain target. Judging from its purpose, according to Sunyoto (2013:17) The motivation given to employees or someone of course has a purpose among others, (1) encouraging the passion and spirit of employees. (2) Improve the moral and work satisfaction of employees. (3) Increase employee productivity. (4) Maintain employee loyalty and stability. (5) Improve the discipline and decrease the employee attendance level. (6) Creating a good atmosphere and working relationship. (7) Increase creativity and employee participation. (8) Improve employee welfare. (9) Heightens the sense of employee's responsibility for work and work. That motivation can be stimulated by outside factors but that motivation grows in one's self. A person's motivation is not a stand-alone indicator. The motivation itself arises as a result of interactions occurring within the individual.

Danim (2004) states that there are several factors that affect the motivation, namely (1) The leadership style of the administrator is a leadership with the authorship force making workers depressed and indifferent. (2) Individual attitudes are individual attitudes of a person different from one to another, there are static and existing individuals who are dynamic, there are individuals who are motivated by high work and there are low motivation. The situation and circumstances outside the individual affect motivation. However, the most decisive is in the individual itself. (3) Work situation, work environment, mileage and available facilities evoke motivation if conditions are met. However, if these requirements are not observed and are not met can suppress motivation. A person can work well when the supporting factors are met, as well as vice versa.

According to Afriyani (2013:11) The traits of people working with Termotovasi are as follows: (1) working in accordance with standards, work can be resolved according to the target organization. (2) Be happy in working, something that is done because of the motivation that encourages him will make someone happy to do his job. (3) feeling valuable, a person will feel precious when doing a job motivated from within him or from outside. (4) Working hard, a person will work hard because of such a high impulse to produce a predetermined work. (5) Little oversight, performance will be monitored itself and does not require too much oversight.

\section{Organizational Citizenship Behaviour (OCB)}

Robbins and Judge (2008:40) defined OCB as a preferred behaviour that was not part of an employee's formal work obligation, but effectively supported the organization's functioning. Shweta and Srirang (2009:32) stated that OCB is characterized by any effort of any kind made at the discretion of the employee who provides benefits to the organization without expecting any remuneration. Kumar et al. (2009:12) defines OCB as individual behaviour that contributes to the creation of organizational effectiveness and is not directly related. According to Dita (2013:17), employee behaviour in the workplace is grouped into two types, i.e. behaviors relating to their official (in role behavior) duties and behaviors outside of their official roles (extra role behavior). The behavior of extra role behavior is crucial to the effectiveness of the Organization, which in the long term affects the life continuity of the organization. The behavior of extra role behavior is also called an extra role or Organizational Citizenship Behaviour (OCB).

According to the titular title (2014:15) of Organizational Citizenship Behaviour (OCB) is influenced by two main factors: (1) internal factors derived from self-employee, such as work satisfaction, commitment, and personality, employee moral, motivation, etc. (2) Organizational Citizenship Behaviour (OCB) is influenced by external factors originating from outside employees, such as leadership styles, trust in leaders, organizational culture, etc.

Factors affecting Organizational Citizenship Behaviour (OCB) between one and the other are related, including: (1) Personality and mood (mood). Personality and mood have an influence on the emergence of the behavior of Organizational Citizenship Behaviour (OCB) both individually and in groups. George and Brief (Dita, 2013:22) argue that someone's willingness to help others is influenced by the mood. Personality 
is a characteristic that can be relatively permanent, while the mood is a characteristic that can change. (2) Employment period. Dita (2013:22) suggests that personal characteristics such as working period are influential in Organizational Citizenship Behaviour (OCB). The same is stated by Summer et al, the work period can serve as the predictor of Organizational Citizenship Behaviour (OCB) because these variables represent "measurements" of the "investment" of employees in the organization. Employees who have long cooperated in an organization will have a close and strong interest in the organization. A long working period will also increase the confidence and competition of employees in doing their work, as well as a feeling of positive feelings and interest in the organization.

According to the titular title (2014:7) The dimensions of Organizational Citizenship Behaviour (OCB) are as follows: (1) Altruism, the behavior of employees in helping his co-workers who have difficulties in the situation that is facing good about the tasks in the Organization and personal problems of others. This dimension leads to giving help that is not an obligation he has taken. (2) Conscientiousness, behavior by attempting to exceed the expected company. Voluntary conduct that is not an employee's obligation or duty. This dimension spans far above and is far ahead of the task call. (3) Sportsmanship, behaviors that provide tolerance to the less than ideal circumstances in the organization without filing objections. A person who has a high degree in Sportsmanship will increase the positive climate among employees, employees will be more polite than working with others and will create a more enjoyable work environment. (4) Courtesy, maintaining good relations with its coworkers in order to avoid interpersonal issues. A person who has this dimension is the one who appreciates and pays attention to others. (5) Civic Virtue, a behaviour that indicates responsibility for organizational life (following changes in the organization, takes the initiative to recommend how organizational operations or procedures can be improved, and protect the resources owned by the organization). This dimension leads to the responsibility that the organization provides to the person to improve the quality of the field of work.

\section{Transformational Leadership Style}

Samsudin (2006:287) says that leadership is the ability to convince and move others in order to cooperate under his leadership as a team to achieve a particular goal. While the leadership style of a leader is unique and cannot be inherited as automatic. Each leader has certain characteristics arising in different situations.

Natsir (2004:2-3) said that the transformational leadership as a leader or superiors influence the subordinates. The subordinates felt trust, pride, loyalty and respect to the boss, and they were motivated to do beyond what was expected. The transformational leadership should be able to clearly interpret the vision for the organization, so that its followers will receive the credibility of the leader (Su-Yung Fu, 2000). According to Case (2003), that the main function of a transformational leader is to provide service as a catalyst of change, but at the same time as a controller of change. Case (2003), saying "that although there are some differences in defining transformational leadership, it is generally common that they interpret it as a change agent".

The transformational leadership essentially has four characteristics, namely the ideal influence, inspirational motivation, intellectual stimulation, and individual attention (YUKL: 2005): (1) The ideal influence. The transformational leader provides a positive example in attitudes and behaviors, for his subordinates. The leader takes care of his subordinates, gives vision, and instills pride in his subordinates. Through this kind of influence, the subordinates will put respect and trust in the leader, so that they desire to do the same as the leaders do. (2) inspirational motivation. Inspirational motivation is the ability to communicate expectations and to express goals in simple ways. The transformational leader could stimulate his subordinates ' enthusiasm to work in the group and develop subordinate beliefs to achieve common objectives and inspire an inspirational work spirit, encouraging employees to increase performance beyond their own expectations. (3) Intellectual stimulation. Transformational leaders strive to create a climate conducive to idea development. Therefore, subordinates are actually involved in the process of formulating problems and finding solutions. Disagreements are seen as common things. It will make the subordinate's self-efficacy stronger, so that the subordinates will be able to work and succeed in performing various challenging tasks. (4) Individualized consideration. Transformational leaders pay attention to their subordinates personally, respecting each individual's differences, giving advice and appreciation. Personal attention is an initial 
identification of the potential subordinates, while monitoring and routing is a form of personal attention that is applied through the actions of consultation, advice and guidance provided by the transformational leader.

There are several indicators of transformational leadership style according to Robbins (2010:263): (1) Kharisma. Charisma is regarded as a combination of charm and personal attractiveness that contributes to the extraordinary ability to make others support the vision and also promote it enthusiastically. The charismatic leader is the leader who creates an atmosphere of motivation on the basis of commitment and emotional identity to their vision, philosophy, and style in his own. (2) Inspiring motivation. Inspiring motivation illustrates a passionate leader in communicating the future of an idealistic organization. Leaders use verbal communication or the use of symbols aimed at promoting subordinate spirits. Leaders motivate subordinates to the importance of organizational vision and mission so that all his subordinates are encouraged to have the same vision. This similarity of vision spurred subordinates to work towards achieving long-term goals with optimism. So that leaders not only raise the spirit of individuals but also team spirit. (3) Intellectual stimulation. Intellectual stimulation describes the leader being able to encourage employees to solve old problems in a new way. Leaders strive to encourage attention and subordinate awareness of the problems faced. Leadership then seeks to develop subordinate abilities to solve problems with new approaches or perspectives. (4) Individual attention. Individual attention illustrates that the leadership always pays attention to its employees, treating employees individually, training and advised. The leader invites employees to see the abilities of others. Leaders focus employees on developing personal strengths.

\section{Employee Performance}

Wirawan (2009:5) defines performance as an output produced by the functions or indicators of a job or a profession within a given time. Sulistiyani and Rosidah (2003:276) expressed a person's performance is a combination of ability, effort, and opportunity to be assessed from his work. According to the title (2014:74) of performance is a description of the level of achievement of the implementation of an activity/program/discretion in realizing the objectives, objectives, vision and mission of the organization that is contained in the formulation of a strategic scheme of an organization that is in the formulation of strategic schemes of an organization. Mamik (2010:88) stated that employee performance is the result of work achieved by an employee in carrying out its work in accordance with the standards and criteria set forth for the work. In line with the opinions of Mangkunegara (2000:67) stating that the performance of employees is the result of work of employment and quantity achieved by an employee in carrying out his duties in accordance with the responsibilities given to him. So it can be concluded that the performance definition of employees ' work both quality and quantity achieved by the employee in a certain period according to the responsibilities given.

According to Mulyadi (2015:63) Factors affecting performance achievement are: (1) The ability factor, psychologically, the ability of the employee consists of a potential capacity (IQ) above average (IQ 110-120) with adequate education for the position and skilled in working on the daily work, so it will be easier to achieve the expected performance. (2) Motivation factor, mental attitude is a mental that encourages an employee to strive to achieve maximum work achievement. The mental attitude of an officer must be psychophysical prepared mental attitude (physical ready, goals, and situations) meaning that an employee must be mentally and physically prepared and understand the main objectives and target work to be achieved.

According to Nurandini (2014:21), performance is essentially what employees are doing. General employee performance for most jobs includes the following elements: (1) Working quantity. The work quantity is in completing the task the job can meet the expected target. (2) Quality of work. Quality of work is the result of work within a certain time period. (3) timeliness. Timeliness is the ability to solve problems precisely and correctly faced when carrying out tasks without relying on decisions from superiors. (4) attendance. Attendance is the extent to which employees timely, observe a prescribed rest period and a record of attendance as a whole. 


\section{Conclusion}

After doing the discussion and testing in the previous chapters of both the hypothesis testing and the discussion of the research results, the following conclusions can be withdrawn:

a. The motivation of work is significant impact on Organizational Citizenship Behaviour in the employees of BMT UGT Sidogiri Jember.

b. Transformational leadership style significant effect on Organizational Citizenship Behaviour on BMT UGT Sidogiri Jember employees.

c. Work motivation is significant effect on the performance of BMT UGT Sidogiri Jember employees.

d. Transformational leadership style significant effect on performance in BMT UGT Sidogiri Jember employees.

e. Organizational Citizenship Behaviour has significant effect on the performance of BMT UGT Sidogiri Jember employees.

f. Work motivation has a significant impact on performance through Organizational Citizenship Behaviour on employees of BMT UGT Sidogiri Jember.

g. Transformational leadership style significant effect on performance through Organizational Citizenship Behaviour on BMT UGT Sidogiri Jember employees.

\section{Limitations}

The limitations in this study are the factors that affect the performance of employees, in this study consists only of two independent variables, namely the motivation and style of transformational leadership and one variable intervening namely Organizational Citizenship Behaviour. While there are still many other factors that affect employee performance. Data retrieval using the questionnaire can also be a limitation in this study because the answers given by respondents sometimes do not reflect the real state.

\section{Acknowledgements}

The author wants to thank the various parties, from BMT UGT SIDOGIRI Jember who has been willing to provide opportunities for research to use the company as a research object, for employees BMG UGT SIDOGIRI Jember which is an example of study respondents, and academics who helped write and resolve this article, not only in the form of data sources but also ideas, so the author can accomplish this interesting article that can be read and studied further The author also received constructive advice and criticism for the perfection of this article.

\section{References}

[1.] Aini, Nur., Suhermin, 2016, Pengaruh Motivasi, Komitmen Organisasi, OCB Dan Disiplin Kerja Terhadap Kinerja Karyawan, Jurnal Ilmu dan Riset Manajemen : Volume 5, Nomor 9, September 2016.

[2.] Arikunto, 2006, Prosedur Penelitian Suatu Pendekatan Praktik, Jakarta: PT. Rineka Cipta.

[3.] Anna Suzana, 2017, Pengaruh Organizational Citizenship Behavior (OCB) Terhadap Kinerja Karyawan (Studi di PT Taspen (Persero) Kantor Cabang Cirebon), Jurnal Logika, Vol XIX No 1 April 2017.

[4.] Antonio, Nio Erick., Eddy M. Sutanto, 2014, Pengaruh Motivasi Dan Kepuasan Kerja Karyawan Terhadap Organizational Citizenship Behavior di CV Supratex, Universitas Kristen Petra.

[5.] Apriyanto, Wawan., R. Budhi Satrio, 2015, Pengaruh Gaya Kepemimpinan Transformasional Dan Motivasi Kerja Terhadap Kinerja Karyawan, Jurnal Ilmu dan Riset Manajemen Volume 4, Nomor 11, November 2015.

[6.] Atmaja, I Komang Adi Wira., I Gst. Ayu Dewi Adnyani, 2016, Pengaruh Gaya Kepemimpinan Transformasional Dan Komitmen Organisasional Terhadap Organizational Citizenship Behavior, E-Jurnal Manajemen Unud, Vol. 5, No. 11, 2016.

[7.] Badeni, 2013, Kepemimpinan dan Perilaku Organisasi, Bandung: Alfabeta.

[8.] Damaryanthi, Anak Agung Inten., Anak Agung Kartika Dewi, 2016, Pengaruh Kecerdasan Emosional, Komitmen Organisasi, Dan Organizational Citizenship Behavior Terhadap Kinerja Pegawai FEB, E-Jurnal Manajemen Unud, Vol. 5, No. 2, 2016. 
[9.] Danendra, AA Ngurah Bagus., Ni Wayan Mujiati, 2016, Pengaruh Motivasi, Kompensasi Dan Komitmen Organisasional Terhadap Organizational Citizenship Behavior (OCB), E-Jurnal Manajemen Unud, Vol. 5, No. 10, 2016.

[10.] Danim, S, (2004), Motivasi kepemimpinan dan efektivitas kelompok. Jakarta: Asdi Mahasatya.

[11.] Dita Yulia Amanda, 2013, Pengaruh Disiplin Kerja dan Komitmen Organisasi terhadap Kinerja Karyawan Melalui Organizational Citizenship behavior (OCB) PT. Bank Raklyat Indonesia (Persero) Tbk. Unit Universitas Jember. Tidak Diterbitkan, Skripsi Jember : Universitas Jember.

[12.] Elfina, Debora Purba Seniati, Ali Nina Liche, 2007, Pengaruh Kepribadian dan Komitmen Organisasi terhadap Organizational Citizenship Behaviour, Makara, Sosial Humaniora, Vol.8, No.3, Desember 2004.

[13.] Hasibuan, Malayu S.P, 2006, Manajemen Sumber Daya Manusia Jakarta: PT Bumi Aksara.

[14.] Kumala Devi, Ni Putu Ayu Archita., Desak Ketut Sintaasih, Organizational Citizenship Behavior, Kepemimpinan Transaksional, Dan Komitmen Organisasional: Pengaruhnya Terhadap Kinerja Karyawan, E-Jurnal Manajemen Unud, Vol. 5, No. 10, 2016.

[15.] Lamidi, 2008, Pengaruh Kepemimpinan Transformasional Terhadap Organizational Citizenship Behavior : Dengan Variabel Intervening Komitmen Organisasional, Jurnal Ekonomi dan Kewirausahaan, Vol 8, No 1.

[16.] Larasati, Sindi., Alini Gilang, 2014, Pengaruh Motivasi Kerja terhadap Kinerja Karyawan Wilayah Telkom Jabar Barat Utara (Witel Bekasi), Universitas Telkom Bandung 2014.

[17.] Mamik, 2010, Pengaruh Gaya Kepemimpinan, Motivasi Kerja, dan Komitmen Organisasi Terhadap Kinerja Karyawan, Jurnal Ekonomi, 2010.

[18.] Mangkunegara, A.A. Anwar Prabu, 2000, Manajemen Sumber Daya Manusia Perusahaan, Bandung : PT. Remaja Rosdakarya.

[19.] Manullang, 2001, Manajemen Sumber Daya Manusia. Yogyakarta : BPFE.

[20.] Mulyadi, 2015, Manajemen Sumber Daya Manusia, Bogor: In Media.

[21.] Nitasari, Rizka Afrisalia, 2012, Analisis Pengaruh Motivasi Kerja Terhadap Kinerja Karyawan Dengan Kepuasan Kerja Sebagai Variabel Intervening Pada PT Bank Central Asia Tbk. Cabang Kudus, Skripsi, Universitas Diponegoro.

[22.] Noer Aisyah Barlian, Pengaruh Tipe Kepribadian, Kontrak Psikologis, Komitmen Organisasi, Motivasi dan Kepuasan Kerja terhadap Organizational Citizenship Behavior (OCB) dan Kinerja Karyawan di Rumah Sakit Paru Kabupaten Jember, Jember : Universitas Jember, 2016.

[23.] Rahmi, B. Maptuhah. 2013. Pengaruh Kepemimpinan Transformasional Terhadap Organizational Citizenship Behavior dan Komitmen Organisasional Dengan Mediasi Kepuasan Kerja (Studi pada Guru Tetap SMA Negeri di Kabupaten Lombok Timur). Tesis. Universitas Udayana.

[24.] Robbins, Stephen, P, 2007, Perilaku Organisasi, Cetakan Kedua, PT. Macanan Jaya Cemerlang Indonesia.

[25.] Sedarmayanti, 2016, Manajemen Sumber Daya Manusia, Cetakan Kelima, Bandung: Refika Aditama.

[26.] Slamet Riyadi, Pengaruh Kompensasi Finansial, Gaya Kepemimpinan, dan Motivasi Kerja terhadap Kinerja Karyawan pada Perusahaan Manufaktur di Jawa Timur, Jurnal Manajemen dan Kewirausahaan, Vol.13, No. 1, Maret 2011.

[27.] Subhi, Emil Ryan., Tri Yuniati 2014, Pengaruh Kepemimpinan Transformasional Terhadap Kinerja Karyawan Dengan Penghargaan Sebagai Variabel Moderating, Jurnal Ilmu \& Riset Manajemen Vol. 3 No. 2. 2014.

[28.] Sugiyono, 2012, Metode Penelitian Kuantitatif, Kualitatif, dan R\&D, Bandung: Alfabeta.

[29.] Titisari, Purnamie, 2014, Peranan Organizational Citizenship Behaviour (OCB) Dalam Meningkatkan Kinerja Karyawan, Jakarta: Mitra Wacana Media.

[30.] Yukl, G. 2005, Kepemimpinan dalam organisasi, Edisi Kelima. Jakarta: Indeks. 